This article was downloaded by: [National Taiwan University]

On: 17 December 2008

Access details: Access Details: [subscription number 788846425]

Publisher Taylor \& Francis

Informa Ltd Registered in England and Wales Registered Number: 1072954 Registered office: Mortimer House, 37-41 Mortimer Street, London W1T 3JH, UK

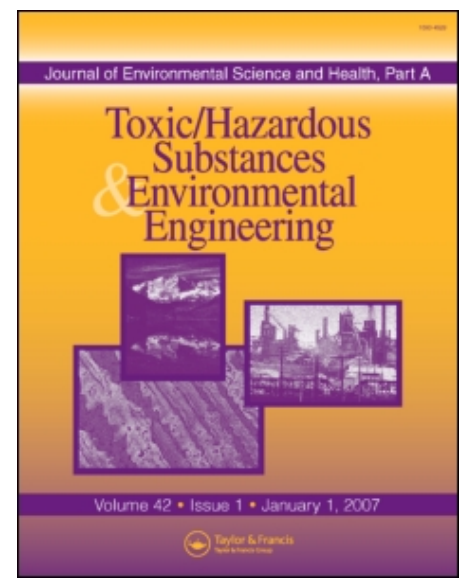

Journal of Environmental Science and Health, Part A

Publication details, including instructions for authors and subscription information: http://www.informaworld.com/smpp/title content=t713597268

\title{
The Effectiveness of a New Gas-Induced Reactor in Treating Phenolic Wastewater by Ozonation and Hydrogen Peroxide
}

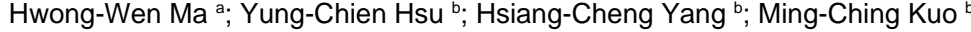

a Graduate Institute of Environmental Engineering, National Taiwan University, Taipei, Taiwan ${ }^{\mathrm{b}}$ Department of Chemical Engineering and Technology, National Taiwan Institute of Technology, Taipei, Taiwan

Online Publication Date: 01 May 2003

To cite this Article Ma, Hwong-Wen, Hsu, Yung-Chien, Yang, Hsiang-Cheng and Kuo, Ming-Ching(2003)'The Effectiveness of a New Gas-Induced Reactor in Treating Phenolic Wastewater by Ozonation and Hydrogen Peroxide',Journal of Environmental Science and Health, Part A,38:4,619-630

To link to this Article: DOI: $10.1081 /$ ESE-120016926

URL: http://dx.doi.org/10.1081/ESE-120016926

\section{PLEASE SCROLL DOWN FOR ARTICLE}

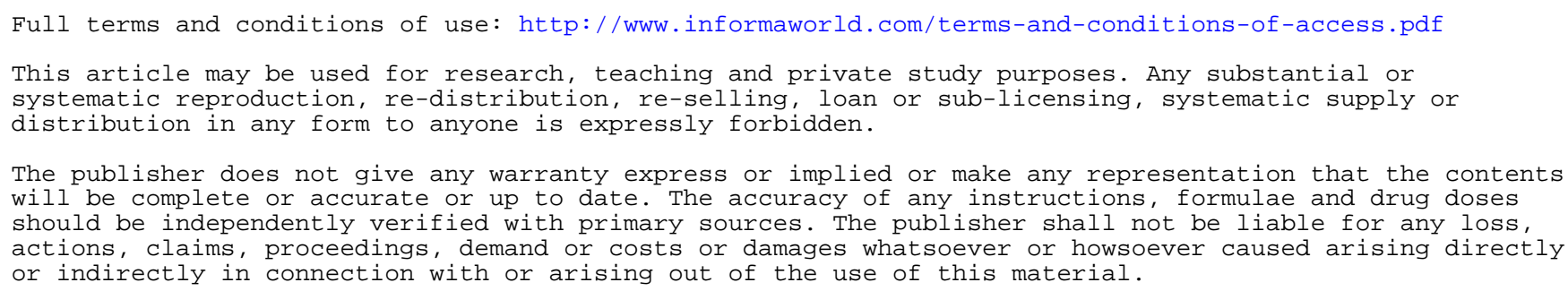




\title{
The Effectiveness of a New Gas-Induced Reactor in Treating Phenolic Wastewater by Ozonation and Hydrogen Peroxide
}

\author{
Hwong-Wen Ma, ${ }^{1, *}$ Yung-Chien $\mathrm{Hsu}^{2}{ }^{2}$ Hsiang-Cheng Yang, ${ }^{2}$ \\ and Ming-Ching Kuo ${ }^{2}$ \\ ${ }^{1}$ Graduate Institute of Environmental Engineering, \\ National Taiwan University, Taipei, Taiwan \\ ${ }^{2}$ Department of Chemical Engineering and Technology, \\ National Taiwan Institute of Technology, Taipei, Taiwan
}

\begin{abstract}
A new Gas-Induced Reactor (GIR) has been developed to improve the efficiency of ozone utilization in water treatment. In this study, the GIR was used to investigate the behavior of ozonation of aqueous phenol solution by means of $\mathrm{O}_{3}$ and $\mathrm{O}_{3} / \mathrm{H}_{2} \mathrm{O}_{2}$ processes in order to explore the feasibility and efficiency of treating such wastewater using the new GIR. The study observed the decomposition of phenol, utilization of ozone, and variation of TOC during ozonation, varying $\mathrm{pH}$ values, phenol initial concentrations, ozone input concentrations, and hydrogen peroxide dosages. The study concluded that the new GIR was capable of performing effective and efficient ozonation of phenolic wastewater, maintaining high ozone utilization ratios at all experimental $\mathrm{pH}$ values and initial phenol and ozone concentrations. The optimal $\mathrm{pH}$ condition for phenol removal was around 11. The best molar ratios of initial hydrogen peroxide over input ozone among the performed experiments were about 20 at $\mathrm{pH} 7$ and 10
\end{abstract}

*Correspondence: Hwong-Wen Ma, Graduate Institute of Environmental Engineering, National Taiwan University, 71 Chou-Shan Rd., Taipei, Taiwan 106; E-mail: hwma@ccms.ntu.edu.tw.

DOI: $10.1081 /$ ESE-120016926

Copyright $\odot 2003$ by Marcel Dekker, Inc.
1093-4529 (Print); 1532-4117 (Online) www.dekker.com 
at $\mathrm{pH} 9$ and 11. The primary operational energy used for treating a tonne of wastewater was $66 \mathrm{MJ}$, giving treatment costs of about US\$1.0 per tonne.

Key Words: Gas-induced reactor; Advanced oxidation process; Ozone; Hydrogen peroxide; TOC.

\section{INTRODUCTION}

Phenolic compounds are of concern because of their toxicity and biorefractory characteristics ${ }^{[1,2]}$ For example, the U.S.EPA has ranked phenol, dichlorophenol, trichlorophenol, pentachlorophenol, chloromethyl phenol, 2,4-dimethyl phenol, and nitrosophenol among 129 priority toxic pollutants. Phenolic compounds exist widely in the wastewater released from oil-refining, coking, petrochemical, painting, steel, and textile industries: ${ }^{[3,4]}$ these residuals will lead to serious environmental problems if not subject to appropriate treatment.

Based on phenol concentration, composition of wastewater, and cost, the techniques used for treating phenol-containing wastewater are usually selected from recycling, incineration, ${ }^{[5]}$ adsorption,${ }^{[6]}$ bio-treatment, ${ }^{[7]}$ or chemical oxidization. ${ }^{[8,9]}$ With advancing pollutant-controlling technologies and more stringent regulatory environmental standards, the combination of the advanced oxidation process (AOP) with biological treatment in treating wastewater has been widely discussed. Ozone can break down many refractory organics effectively because as a strong oxidant it is decomposed in aqueous solutions to produce stronger hydroxyl radicals. ${ }^{[10,11]}$ However, in spite of the merits of ozone, its use is limited by high generation cost and low ozone utilization ratio. The utilization of ozone is hampered by the mass transfer resistance between gas and liquid phases. ${ }^{[12,13]}$ To address this vital issue, a new gas-induced reactor (GIR) has been developed to promote the utilization efficiency of ozone by enhancing the transfer between gas and liquid phases. The characteristics of the GIR and the associated optimal geometric configuration have been provided in early studies. ${ }^{[14,15]}$ This research was aimed at investigating the feasibility of treating phenolic wastewater with the new developed GIR. By changing $\mathrm{pH}$ value, initial concentration of phenol, input ozone concentration, and $\left[\mathrm{H}_{2} \mathrm{O}_{2}\right] /\left[\mathrm{O}_{3}\right]$ ratio, the ozone utilization ratios as well as the rates of phenol removal and TOC degradation during the treatment process were explored to assess the GIR's potential in phenol-containing wastewater treatment.

\section{EXPERIMENTAL}

\section{Instrumentation}

Figure 1 shows the experimental apparatus, primarily consisting of the GIR, an ozone generator, and an ozone analyzer. The reactor was an acrylic resin cylinder, with $17 \mathrm{~cm}$ inside diameter, $0.5 \mathrm{~cm}$ thickness and $80 \mathrm{~cm}$ height, which was surrounded by a thermostatic jacket to maintain a constant temperature of $25^{\circ} \mathrm{C}$ 


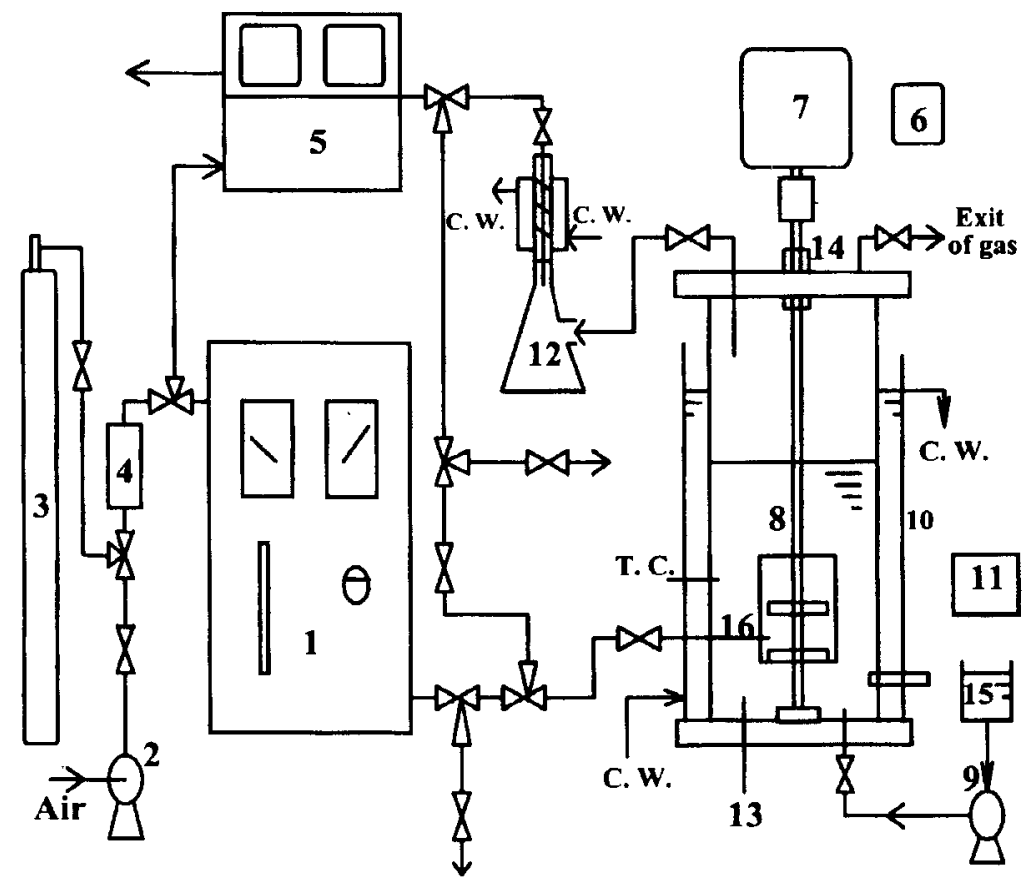

1. Ozone generator

2. Air compressor

3. Oxygen cylinder

4. Moisture removal device

5. Ozone analyzer

6. Torque meter

7. Motor

8. Gas-induced reactor
9. Dosing pump

10. Thermostatic jacket

11. $\mathrm{pH}$ meter

12. Vapor condensing device

13. Liquid sampling port

14. Mechanical seal

15. $\mathrm{NaOH}$ solution vessel

16. Gas pipe for ozone

Figure 1. Experimental apparatus.

in all experiments. A $\mathrm{pH}$ meter connected with a $\mathrm{pH}$ controller was used to maintain the $\mathrm{pH}$ at a preset value. The Seki-Electronics (Japan) model SOZ-302C UV photometric analyzer calibrated by KI titration method was used to measure the ozone concentration in the gas phase. The Spectra-Physics (USA) model SP8800 HPLC was used to measure phenol aqueous concentrations while ASTRO (USA) model 2001 TOC analyzer was used to gauge TOC. Detailed description of the apparatus refers to Hsu and Huang. ${ }^{[14,15]}$

\section{Experimental Procedures}

Seven liters of phenol solution with desired initial concentrations $\left(C_{0}=50,100\right.$, 300 , and $600 \mathrm{mg} / \mathrm{L}$ ) were put into the reactor and the $\mathrm{pH}$ was adjusted to specific 
levels $\left(\mathrm{pH}=3,7,9,11\right.$, and 13) by using $\mathrm{NaOH}$ and $\mathrm{H}_{2} \mathrm{SO}_{4}$. When the effects of adding $\mathrm{H}_{2} \mathrm{O}_{2}$ were studied, proper dosage ratios of $\left[\mathrm{H}_{2} \mathrm{O}_{2}\right] /[$ phenol] were used to prepare the $7 \mathrm{~L}$ solution in order to obtain desired $\left[\mathrm{H}_{2} \mathrm{O}_{2}\right] /\left[\mathrm{O}_{3}\right]$ molar ratios $(9,20$, 38 , and 57). The stirring speed was kept at $1500 \mathrm{rpm}$. The ozone generator's gas flow was set at $300 \mathrm{NL} / \mathrm{h}$ with experimental ozone inlet concentrations $\left(C_{\mathrm{O}_{3}, \text { in }}=13,20\right.$, 30,40 , and $50 \mathrm{mg} / \mathrm{NL}$ ). When the ozone generation achieved steady state, ozone was introduced into the reactor and the ozone concentrations in the exit gas were recorded every $20 \mathrm{~s}$ to calculate the ozone utilization ratio, which was defined as the difference between total amount of ozone input and total amount of ozone exit divided by the total ozone input. ${ }^{[14]}$ Samples from the ozonated solution were withdrawn at appropriate intervals. $\mathrm{Na}_{2} \mathrm{~S}_{2} \mathrm{O}_{3} \cdot 5 \mathrm{H}_{2} \mathrm{O}$ was added into the samples to prevent further reaction and then analyzed TOC and phenol concentrations.

\section{RESULTS AND DISCUSSION}

The effects of operational conditions ( $\mathrm{pH}$, initial phenol concentration, and inlet ozone concentration) on the treatment of phenolic aqueous solution and the results of the optimum $\left[\mathrm{H}_{2} \mathrm{O}_{2}\right] /\left[\mathrm{O}_{2}\right]$ ratio investigation are presented and discussed below.

\section{The Effect of $\mathrm{pH}$}

\section{The Rate of Phenol Removal}

Figure 2 shows the variation of phenol concentration at different $\mathrm{pH}$ values during the ozonation process. It was found that the time needed to remove phenol decreased with increase of $\mathrm{pH}$ values, with exception of $\mathrm{pH} 13$. The trend resulted from the fact that phenol existed mostly in molecular form under acid conditions and existed mostly in phenolate ionic form, which was more reactive than the molecular form, in alkaline environment. ${ }^{[16]}$ Also, under alkaline conditions ozone reacted with $\mathrm{OH}^{-}$to form $\mathrm{OH}^{*}$, a stronger oxidant. However, when $\mathrm{pH}$ was even higher $(\mathrm{pH}=13), \mathrm{OH}^{\bullet}$ decomposed to produce ${ }^{\bullet} \mathrm{O}^{-}$, a weaker oxidant, and thus lowered the rate of phenol removal. ${ }^{[17]}$

\section{TOC Degradation}

Figure 3 shows the change of TOC with time at different $\mathrm{pH}$ values. The rate of TOC degradation increased with ascending $\mathrm{pH}$ values, with exception of $\mathrm{pH} 13$, because at higher $\mathrm{pH}$ ozone decomposed to produce a stronger oxidant, $\mathrm{OH}^{\circ}$, which was less selective in organics oxidation and thus mineralized intermediates more completely. ${ }^{[16,17]}$ However, at even higher $\mathrm{pH}(\mathrm{pH}=13)$, the $\mathrm{CO}_{3}^{2-}$ and $\mathrm{HCO}_{3}^{-}$ produced when intermediates were mineralized captured $\mathrm{OH}^{*}$ and subsequently lowered the TOC degradation rate. 


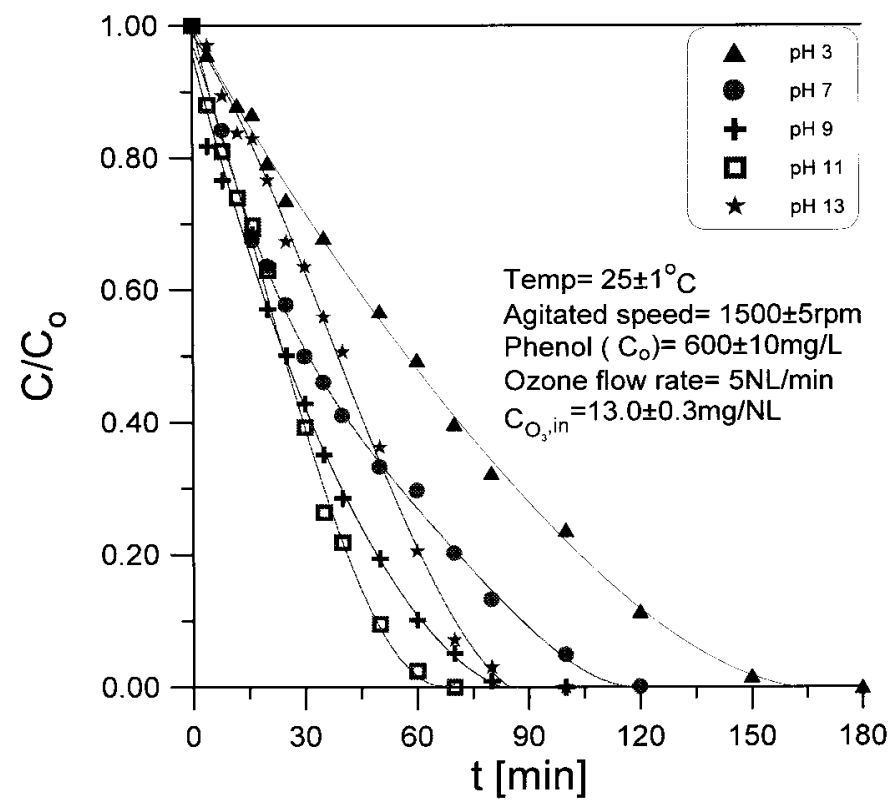

Figure 2. The decomposition of phenol at different $\mathrm{pH}$ values (symbol: $C$ : phenol concentration at time $t ; C_{0}$ : initial phenol concentration; $C_{\mathrm{O}_{3} \text {,in }}$ : input ozone concentration).

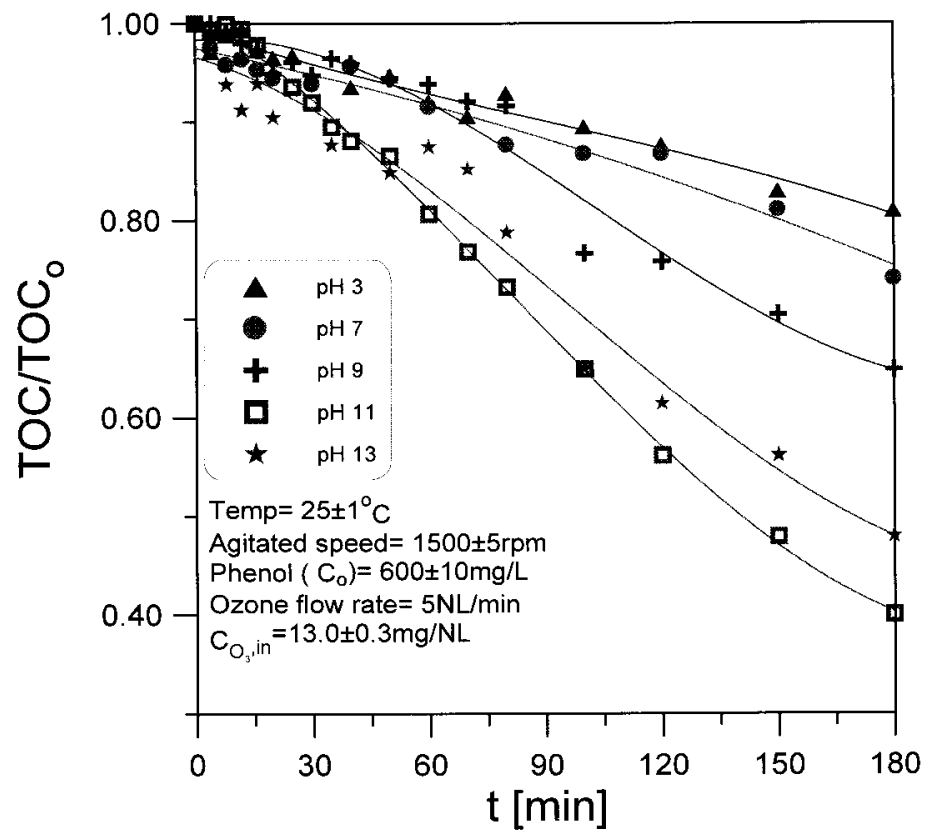

Figure 3. Effect of $\mathrm{pH}$ on TOC decay of phenol solution (symbol: $C_{0}$ : initial phenol concentration; $C_{\mathrm{O}_{3} \text {,in }}$ : input ozone concentration; TOC: TOC at time $t$; $\mathrm{TOC}_{0}$ : initial TOC). 
Table 1. Phenol removal time and ozone consumption rates during ozonation.

\begin{tabular}{crcc}
\hline & $\mathrm{pH}$ & $\begin{array}{c}t \text { at } 90 \% \\
\text { removal }(\mathrm{s})\end{array}$ & $\begin{array}{c}\mathrm{O}_{3} \text { consumption } / \mathrm{phenol} \\
\text { removal }(\mathrm{mg} / \mathrm{mg})\end{array}$ \\
\hline Phenol initial concentration $=600 \mathrm{mg} / \mathrm{L}$ & 3 & 7560 & 1.48 \\
$C_{\mathrm{O}_{3}, \text { in }}=13 \pm 0.3 \mathrm{~g} / \mathrm{m}^{3}$ & 7 & 5262 & 1.326 \\
& 9 & 3620 & 0.927 \\
& 11 & 2978 & 0.765 \\
& 13 & 4186 & 1.08 \\
Phenol initial concentration $=300 \mathrm{mg} / \mathrm{L}$ & 3 & 3600 & 1.496 \\
$C_{\mathrm{O}_{3}, \text { in }}=13 \pm 0.3 \mathrm{~g} / \mathrm{m}^{3}$ & 7 & 3086 & 1.332 \\
& 9 & 1840 & 0.934 \\
& 11 & 1498 & 0.767 \\
& 13 & 1994 & 1.024 \\
Phenol initial concentration $=100 \mathrm{mg} / \mathrm{L}$ & 3 & 1646 & 1.647 \\
$C_{\mathrm{O}_{3}, \text { in }}=13 \pm 0.3 \mathrm{~g} / \mathrm{m}^{3}$ & 7 & 1118 & 1.547 \\
& 9 & 842 & 1.218 \\
& 11 & 801 & 1.206 \\
& 13 & 1057 & 1.615 \\
\hline
\end{tabular}

Note: $t$ : reaction time; ozone flow rate $=5 \mathrm{NL} / \mathrm{min}$.

\section{Ozone Utilization Ratio}

The ozone utilization increased with increasing $\mathrm{pH}$ values. This was because at higher $\mathrm{pH}$ values the generated $\mathrm{OH}^{*}$ reacted with organics rapidly and subsequently increased the driving force of ozone mass transfer from gas phase to liquid phase. As a result, the dissolution and utilization of ozone were increased. However, the amount of ozone consumed for a unit of phenol removal under $\mathrm{pH} 13$ was not the lowest among the five experimental $\mathrm{pH}$ conditions, since there was retardation of the removal rates of phenol and TOC at $\mathrm{pH} 13$ as described previously. Table 1 shows the $\mathrm{O}_{3}$ consumption $(\mathrm{mg})$ per $\mathrm{mg}$ of phenol removal as well as the time needed for $90 \%$ removal for different initial phenol concentrations and $\mathrm{pH}$ values.

The previous results indicated that increasing $\mathrm{pH}$ values promoted the rates of oxidation of phenol and intermediates as well as the efficiency of ozone utilization. However, at $\mathrm{pH} \mathrm{13,} \mathrm{the} \mathrm{benefits} \mathrm{are} \mathrm{reduced.}$

\section{The Effect of Phenol and Ozone Concentration}

\section{Rates of Phenol Removal and TOC Degradation}

Figure 4 shows the variation of phenol concentration with time for different initial phenol concentrations. When input ozone concentration was fixed and the ozone utilization ratio was kept high, the amount of phenol removed was also fixed. Therefore as shown in Fig. 4 the rate of phenol removal decreased with increasing initial phenol concentration. TOC degradation had the same trend. In contrast, 


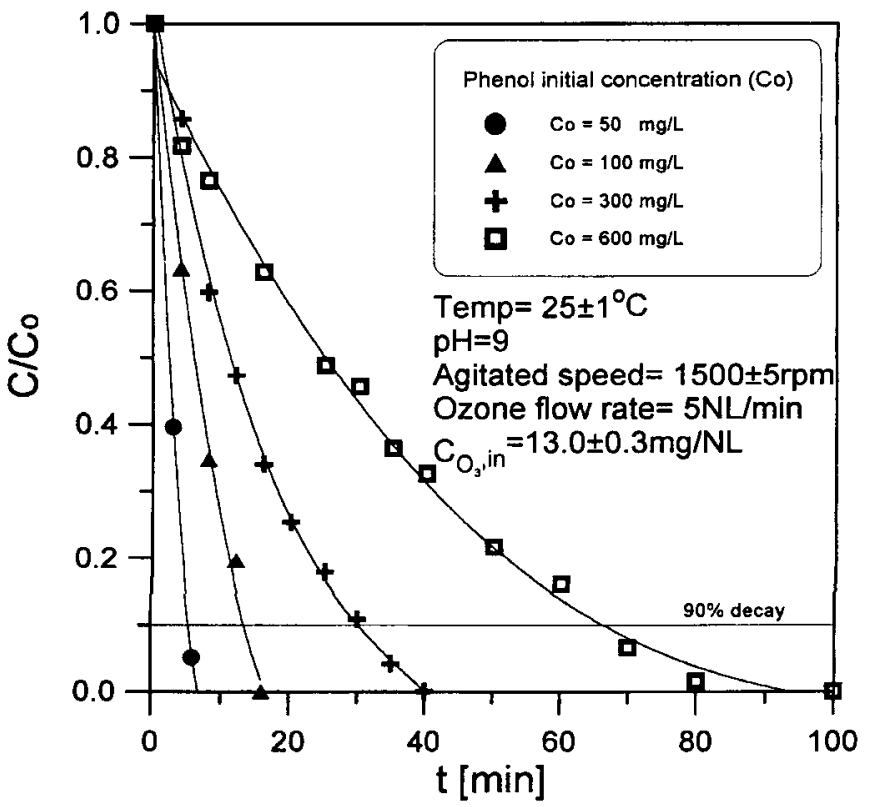

Figure 4. Plot of $C / C_{0}$ vs. time for different initial phenol concentrations (symbol: $C$ : phenol concentration at time $t ; C_{0}$ : initial phenol concentration; $C_{\mathrm{O}_{3} \text {, in }}$ : input ozone concentration).

as increasing input ozone concentration increased the amount of oxidants that reacted with phenol, the removal rates of phenol and TOC increased with increasing input ozone concentration, as shown in Fig. 5 for phenol removal.

\section{Ozone Utilization Ratio}

Figures 6(a) and 6(b) shows the ozone utilization at different initial phenol concentrations and input ozone concentrations, respectively, at $\mathrm{pH}$ 9. It was found that the ozone utilization ratio was greater than $90 \%$ at all phenol and ozone concentrations. In addition to increased dissolution of ozone due to selfdecomposition under the alkaline condition, effectively extending the retention time of ozone in liquid phase in the apparatus, the newly developed GIR enhanced the solubility of ozone and thus promoted the rate of utilization. ${ }^{[15]}$ As also shown in Table 1, the consumptions of ozone per unit of phenol removal were low (ranging from 0.765 to 1.647) at all experimental $\mathrm{pH}$ and initial phenol concentrations. In conventional reactors, a sizable amount of ozone may be released without participating in reactions due to the resistance to mass transfer between gas and liquid phases, and the ozone consumption per unit of phenol removal was usually around 5.2-8.8 ${ }^{[18]}$ The fact that the new GIR provided a better mass transfer and promoted the ozone utilization demonstrated the importance of the reactor in treating phenolic wastewater. 


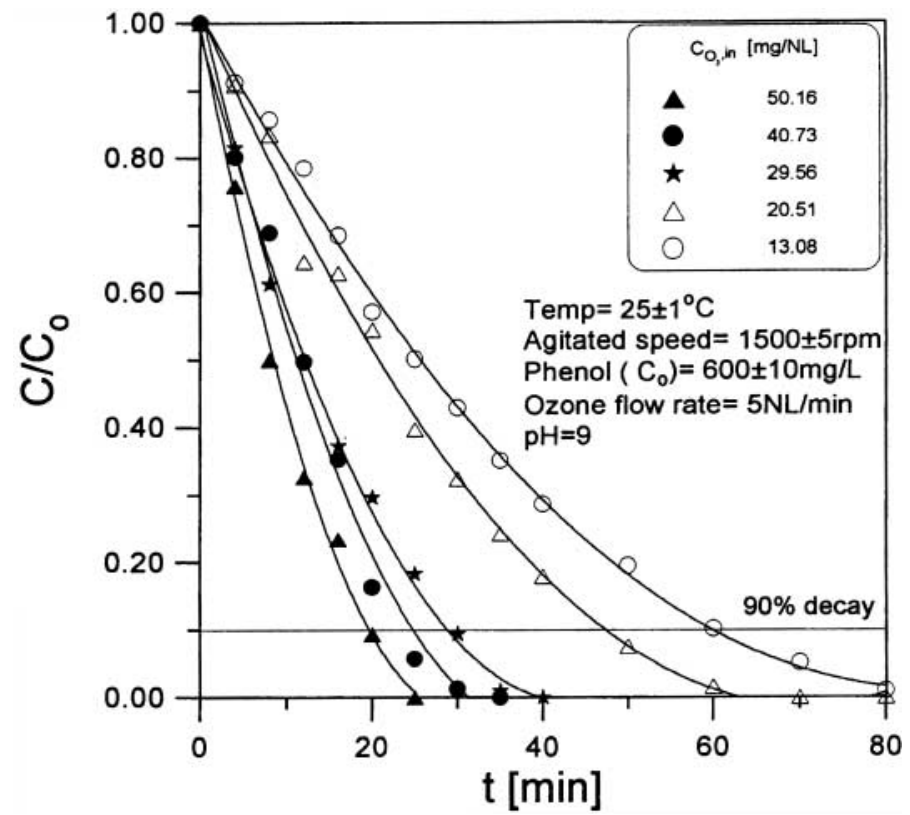

Figure 5. Plot of $C / C_{0}$ vs. time for different ozone inlet concentrations (symbol: $C$ : phenol concentration at time $t$; $C_{0}$ : initial phenol concentration; $C_{\mathrm{O}_{3} \text {, in }}$ : input ozone concentration).

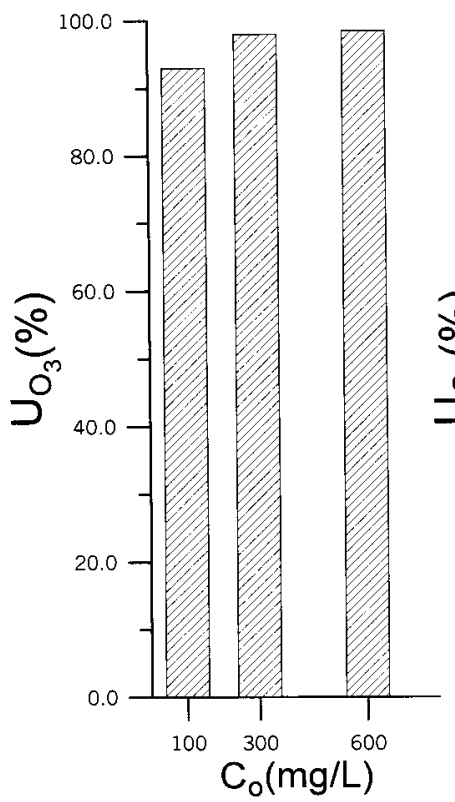

(a)

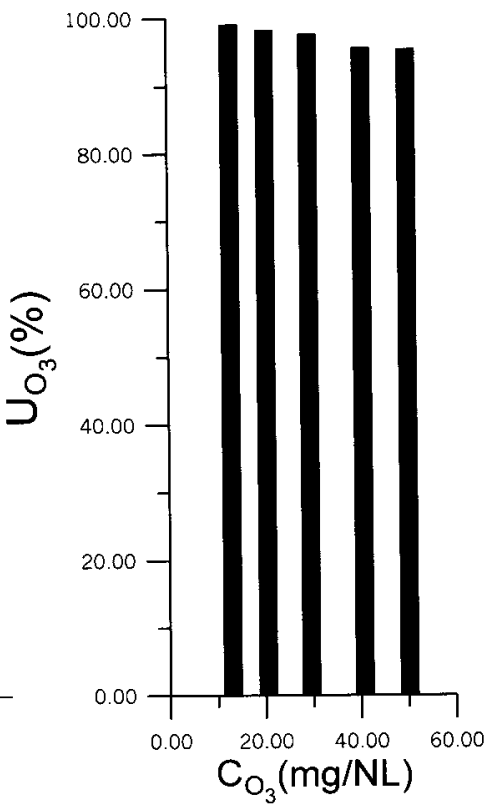

(b)

Figure 6. Ozone utilization ratios at $\mathrm{pH} 9$ and (a) at different initial phenol concentrations, $C_{0}$; (b) at different input ozone concentrations, $C_{\mathrm{O}_{3}, \text { in }}$. 


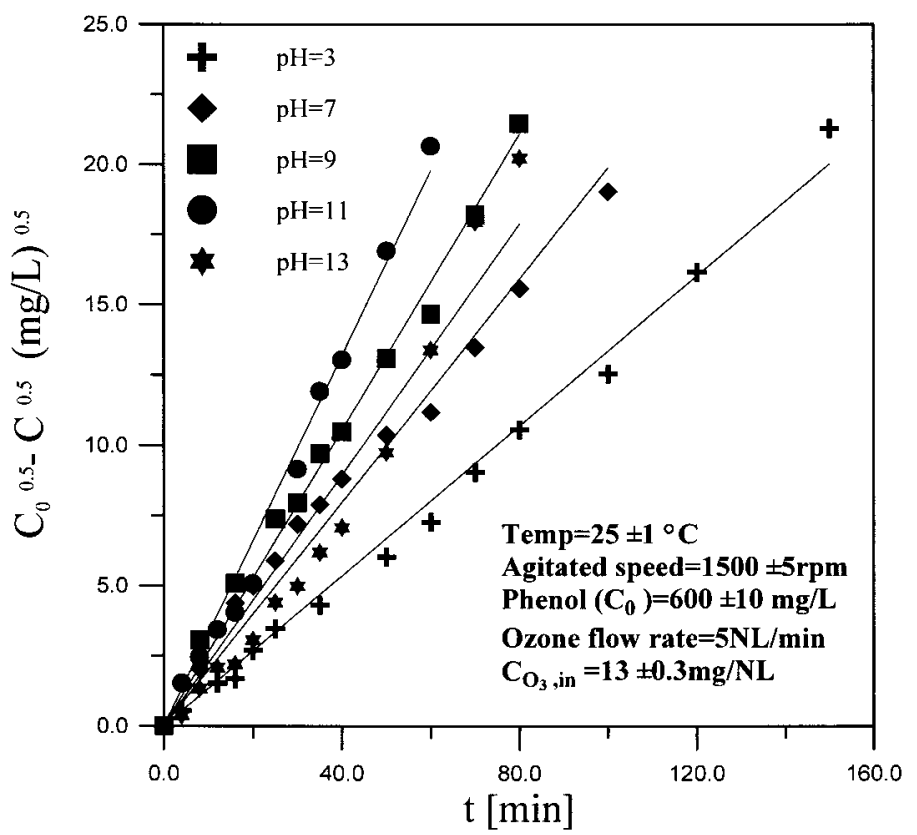

Figure 7. Decomposition kinetics of phenol at different $\mathrm{pH}$ values (symbol: $C$ : phenol concentration at time $t ; C_{0}$ : initial phenol concentration; $C_{\mathrm{O}_{3}, \text { in }}$ : input ozone concentration).

\section{Optimal pH Conditions}

Pseudo 0.5 order kinetics can describe the ozonation of phenol solution in this study. ${ }^{[19]}$ Figure 7 shows that the data fitting conformed to the proposed kinetics. Figure 8 shows the change of the overall removal rate constant, $k_{\mathrm{obs}}$, with $\mathrm{pH}$ for three initial phenol concentrations. The best $\mathrm{pH}$ value was found to be 11 . The result was compatible with that found by Beltran et al. ${ }^{[20]}$

\section{Optimal $\left[\mathrm{H}_{2} \mathrm{O}_{2}\right] /\left[\mathrm{O}_{3}\right]$ Ratio for Phenol Removal}

In order to explore the effect of adding hydrogen peroxide into the ozone reaction system, the change of phenol concentrations with time at different $\left[\mathrm{H}_{2} \mathrm{O}_{2}\right] /\left[\mathrm{O}_{3}\right]$ ratios for $\mathrm{pH} 7,9,11$ were investigated. It was found that, although phenol was degraded faster when hydrogen peroxide was added, in the beginning the removal rates were slower than when hydrogen peroxide was not added. This was because competition between $\mathrm{HO}_{2}^{-}, \mathrm{O}_{3}, \mathrm{OH}^{-}$and phenol for $\mathrm{OH}$ radical at the beginning of the reaction decreased the degradation rate of phenol. The effect of adding hydrogen peroxide under acidic conditions can be ignored because $\mathrm{H}_{2} \mathrm{O}_{2}$, with pKa 11.8, not only reacted very slowly with phenol and ozone but also generated little $\mathrm{HO}_{2}^{-}$. Figure 9 shows how $k_{\text {obs }}$ varied with $\left[\mathrm{H}_{2} \mathrm{O}_{2}\right] /\left[\mathrm{O}_{3}\right]$ at different $\mathrm{pH}$ values. The result indicates that there exists optimal $\left[\mathrm{H}_{2} \mathrm{O}_{2}\right] /\left[\mathrm{O}_{3}\right]$ molar ratios; the best ratios were 20 at $\mathrm{pH} 7$ 


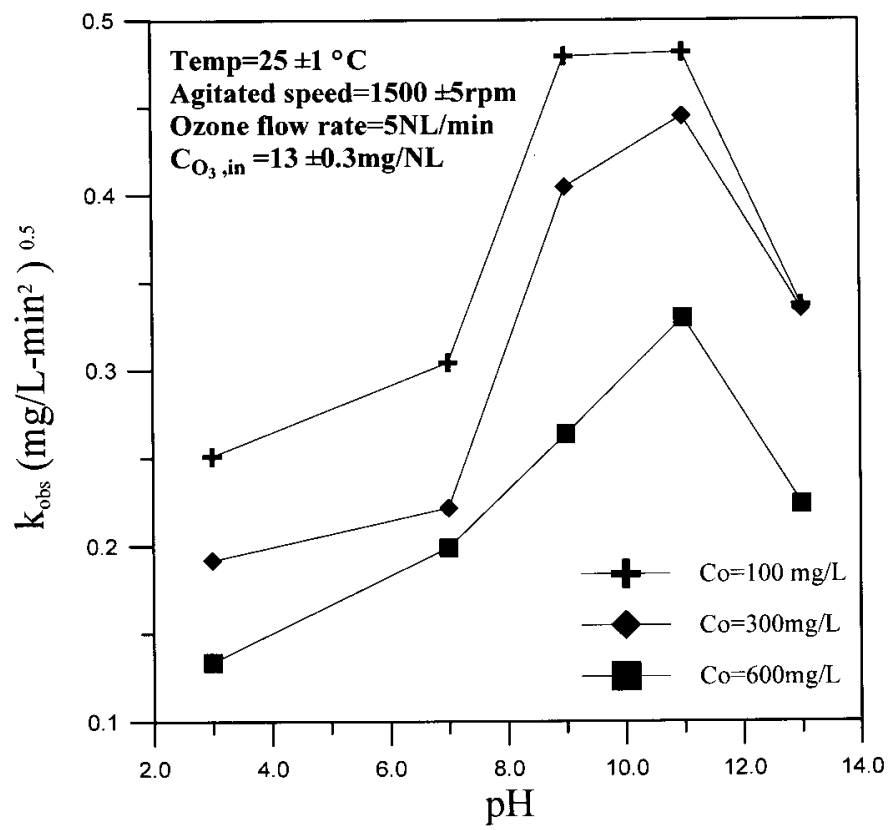

Figure 8. $k_{\mathrm{obs}}$ vs. $\mathrm{pH}$ value for different initial phenol concentrations (symbol: $C_{0}$ : initial phenol concentration; $C_{\mathrm{O}_{3} \text {,in }}$ : input ozone concentration; $k_{\mathrm{obs}}$ : the overall removal rate constant).

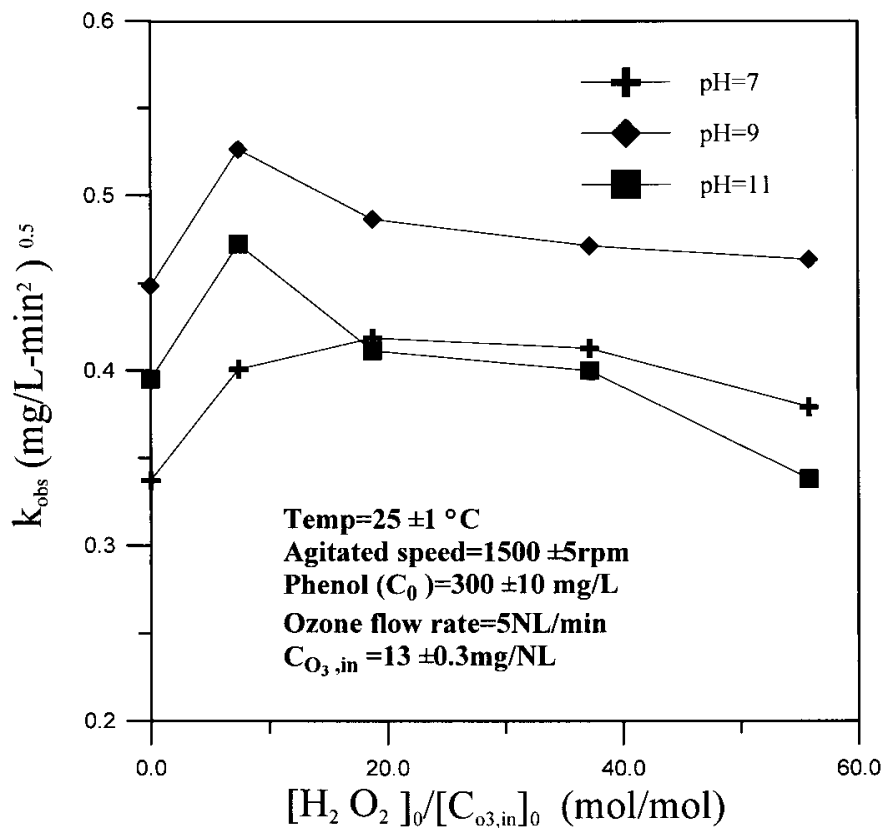

Figure 9. $k_{\mathrm{obs}}$ vs. hydrogen peroxide dosage at different $\mathrm{pH}$ values (symbol: $C_{0}$ : initial phenol concentration; $C_{\mathrm{O}_{3} \text {,in }}$ : input ozone concentration; $k_{\mathrm{obs}}$ : the overall removal rate constant). 
and 9 at $\mathrm{pH} 9$ and 11 among the performed experiments. The addition of more hydrogen peroxide beyond the optimal dosage levels would decrease the reaction rates as a result of competition between phenol, phenol's oxidation intermediates, $\mathrm{H}_{2} \mathrm{O}_{2}, \mathrm{HO}_{2}^{-}$for hydroxyl radicals. ${ }^{[21,22]}$

\section{Primary Operational Cost Estimation}

The electricity needed for generation of ozone and stirring in the GIR was the primary operational cost. The reaction that took $2857 \mathrm{~s}$ to treat $7 \mathrm{~L}$ phenol solution of $600 \mathrm{mg} / \mathrm{L}$ with ozone of $20 \mathrm{mg} / \mathrm{NL}$ at $\mathrm{pH} 9$ is taken as an example. The amperage needed to generate the ozone for $300 \mathrm{NL} / \mathrm{h}$ was $0.65 \mathrm{~A}$, so the energy needed was $0.65 \mathrm{~A} \times 220 \mathrm{~V} \times 2857 \mathrm{~s}$, i.e., $0.408 \mathrm{MJ}$. The power need for stirring the $7 \mathrm{~L}$ solution after deducting the power needed for starting up was $0.019 \mathrm{~kW}$, so the energy required was $0.054 \mathrm{MJ}$. Therefore by ignoring other expenses, the primary operational energy used for treating a ton of wastewater was $66 \mathrm{MJ}$, costing about US\$1.0 per tonne.

\section{CONCLUSION}

This research used a new developed GIR to treat phenol-containing wastewater and found that the reactor was capable of performing effective ozonation of phenolic wastewater. In particular, high rates of ozone utilization were sustained at all experimental $\mathrm{pH}$ values and initial phenol and ozone concentrations. This was a critical improvement to the key issue that the resistance of mass transfer of ozone between gas and liquid phases boosted the operational cost and thus impeded the wide use of ozonation. In addition, the investigation of optimal operational conditions showed that while the removal of phenol and TOC as well as ozonation utilization increased with increasing $\mathrm{pH}$ values and hydrogen peroxide dosages, too high a $\mathrm{pH}$ or excessive hydrogen peroxide dosages reduced treatment efficiency instead of improving it. The optimal molar ratios of initial hydrogen peroxide concentration over input ozone concentration among the performed experiments were found to be 20 at $\mathrm{pH} 7$ and 9 at $\mathrm{pH} 9$ and 11 . Finally the calculated primary operational cost indicated that the GIR could reduce the expenses of treatment by enhancing the ozone utilization.

\section{REFERENCES}

1. Calvosa, L.; Monteverdi, A.; Rindone, B.; Riva, G. Ozone oxidation of compounds resistant to biological degradation. Water Res. 1991, 25, 985-993.

2. Hamdi, M. Toxicity and bio-degradability of olive mill wastewaters in batch an anaerobic digestion. Appl. Biochem. \& Biotech. 1992, 37, 155-163.

3. Grau, P. Textile industry wastewater treatment. Wat. Sci. Tech. 1991, 24, 97-103.

4. Benitez, F.J.; de Heredia, J.B.; Acero, J.L.; Pinilla, M.L. Ozonation kinetics of phenolic acids present in wastewaters from olive oil mills. Ind. Eng. Chem. Res. 1997, 36, 638-644. 
5. Bridle, A.P.; Sachdev, A.K. Thermal Destruction of Chlorophenol Residues, 38th Purdue Industrial Waste Conference Proceedings, 1984; 299-309.

6. Nakhla, G.; Abuzaid, S.; Farooq, S. Activated carbon adsorption of phenolics in oxic system: effect of $\mathrm{pH}$ and temperature variations. Wat. Env. Res. 1994, $66,842-850$.

7. Stowell, J.P.; Jensen, J.N.; Weber, A.S. Sequential chemical/biological oxidation of 2-chlorophenol. Wat. Sci. Technol. 1992, 26, 2085-2087.

8. Davis, A.P.; Huang, C.P. The removal of substituted phenols by a photocatalytic oxidation process with cadmium sulfide. Water Res. 1990, 24, 543-550.

9. Joglekar, H.S.; Sament, S.D.; Joshi, J.B. Kinetics of wet air oxidation of phenol and substituted phenols. Water Res. 1991, 25, 135-145.

10. Staehelin, J.; Hoigne, J. Decomposition of ozone in water in the presence of organic solutes acting as promoters and inhibitors of radical chain reactions. Environ. Sci. Technol. 1985, 19, 1206-1213.

11. Sotelo, J.L.; Beltran, F.J.; Gonzalez, M.; Garcia-Araya, J.F. Ozonation of aqueous solutions of resorcinol and phloroglucinol-II. Kinetics study. Ind. Eng. Chem. Res. 1991, 30, 222-227.

12. Sotelo, J.L.; Beltran, F.J.; Benitez, F.J.; Beltran-Heredia, J. Henry's law constant for the ozone-water system. Water Res. 1989, 23, 1239-1246.

13. Munter, R.; Preis, S.; Kamenev, S.; Siirde, E. Methodology of ozone introduction into water and wastewater treatment. Ozone Sci. Eng. 1993, 15, 149-165.

14. Hsu, Y.-C.; Huang, C.-J. Characteristics of a new gas-induced reactor. AIChE J. 1996, 42, 3146-3152.

15. Hsu, Y.-C.; Huang, K.-F. Effects of geometrical factors on liquid mixing in a gas-induced agitated tank. J. Chem. Tech. Biotechnol. 1997, 68, 222-228.

16. Hoigne, J.; Bader, H. Rate constant of reactions of ozone with organic and inorganic compounds in water: II. Dissociating organic compounds. Water Res. 1983, 17, 185-194.

17. Hoigne, J.; Bader, H. The role of hydroxyl radical reactions in ozonation processes in aqueous solutions. Water Res. 1976, 10, 377-386.

18. Somiya, I. The Technologies of Using Ozone in Water Treatment; Kou Gai Tai Sku Gi Jutsu Dou Yu Kai Publisher: Tokyo, Japan, 1981.

19. Otake, T.; Tone, S.; Kono, K. Photo-oxidation of phenols with ozone. J. Chem. Eng. Jpn. 1979, 12, 289-295.

20. Beltran, F.J.; Encinar, J.M.; Gonzalez, J.M. Industrial wastewater advanced oxidation: part 2. Ozone combined with hydrogen peroxide or UV radiation. Water Res. 1997, 31, 2415-2428.

21. Beltran, F.J.; Gonzalez, M.; Rivas, F.J.; Marin, M. Oxidation of mecoprop in water with ozone and ozone combined with hydrogen peroxide. Ind. Eng. Chem. Res. 1994, 33, 125-136.

22. Beltran, F.J.; Gabriel, O.; Rivas, J. Oxidation of polynuclear aromatic hydrocarbons in water: 4. Ozone combined with hydrogen peroxide. Ind. Eng. Chem. Res. 1996, 35, 891-898.

Received February 27, 2002 